\title{
The Federal Justice act in combating corruption in Southern Brazil
}

Lígia Mori Madeira ${ }^{1}$

Leonardo Geliski 1

1 Universidade Federal do Rio Grande do Sul / Programa de Pós-Graduação em Políticas Públicas, Porto Alegre / RS - Brazil

This article studies the operation of the Federal Regional Court of the 4th Region (TRF4) in the fight against corruption crimes. Judgments produced by the TRF4 criminal courts between 2003 and 2016 underwent text analysis using the dictionary method, seeking to outline the profile of crimes and defendants. Despite the changes in the web accountability institutions, with the outbreak of major federal police operations, technological uses, new legal devices and a high degree of concentration between the agencies, there is a small proportion of grand corruption crime, involving middle and high-ranking bureaucrats and more sophisticated crimes with greater financial value. Crimes involving contraband and petty corruption take up much of the day to day of the judiciary in the south region of the country, at least in the criminal intermediate courts, where the judge appeals decisions coming from specialized and generalist criminal courts.

Keywords: corruption; Federal Justice; street-level bureaucracy.

\section{O combate a crimes de corrupção pela Justiça Federal da Região Sul do Brasil}

Este artigo analisa a atuação do Tribunal Regional Federal da $4^{a}$ Região (TRF4) no combate a crimes de corrupção. Decisões judiciais das turmas criminais entre 2003 e 2016 receberam análise de texto com o método de dicionário, traçando o perfil de crimes e réus. Apesar das mudanças na rede de instituições de accountability, com a deflagração de grandes operações da Polícia Federal (PF), usos tecnológicos, novos dispositivos jurídicos e alto grau de concertação entre agências, constatou-se reduzida parcela de grande criminalidade, envolvendo burocratas de médio e alto escalão e crimes sofisticados e de maior valor financeiro. Crimes de contrabando e descaminho (petty corruption) preponderam no Judiciário Federal do Sul do país, pelo menos nas turmas criminais, que julgam recursos de decisões proferidas por varas criminais especializadas e generalistas.

Palavras-chave: corrupção; Justiça Federal; burocratas de nível de rua.

\section{La actuación de la Justicia Federal en el combate a crímenes de corrupción en la Región Sul de Brasil}

Este artículo analiza la actuación del Tribunal Regional Federal de la Cuarta Región, en el combate a crímenes de corrupción. Las sentencias dictadas entre 2003 y 2016 por las salas de justicia criminal del TRF4 se sometieron al análisis de texto con el método de diccionario para esbozar el perfil de los crímenes y de los acusados. A pesar de los cambios en la red de instituciones de accountability, con el desencadenamiento de grandes operaciones de la Policía Federal, usos tecnológicos, nuevos dispositivos jurídicos y el alto grado de concertación entre las agencias, se constató una reducida porción de alta criminalidad involucrando burócratas de medio y alto escalón y crímenes más sofisticados y de mayor valor financiero. Los crímenes como contrabando y corrupción a pequeña escala (petty corruption) predominan en el Poder Judicial en la región sur del país, al menos en las salas de justicia criminales, que juzgan recursos de sentencias de cortes criminales especializadas y generalistas.

Palabras clave: corrupción; Justicia Federal; burócratas del nivel de la calle.

DOI: http://dx.doi.org/10.1590/0034-761220180237x

Article received on July 9, 2018 and accepted on February 19, 2019.

ISSN: 1982-3134@ (1)

[Original version] 


\section{INTRODUCTION}

The issue of fighting corruption has gained increasing visibility in Brazil. The literature has advanced regarding the study of networks of accountability institutions, presenting a significant analysis of the institutions that make up this network and its cycle of supervision, investigation, and sanction (Praça \& Taylor, 2014). As for the last two phases of the cycle, there is more information available about the work of the Federal Police (PF) and the Ministério Público Federal (Brazilian Public Prosecutor's Office at the federal level) (MPF) (Arantes, 2011a, 2011b; Arantes, Loureiro, Couto, \& Teixeira, 2010), which are the trigger-institutions of the Federal Criminal Justice system. However, there are still few studies about the Federal Justice, its operation and daily activities.

This research ${ }^{1}$ investigates the Federal Criminal Justice system, specifically the Federal Regional Court of the $4^{\text {th }}$ Region (TRF4), Southern Brazil, aiming to understand the processes surrounding the theme of fighting "corruption" in its various forms of criminal classification. The study characterizes the day-to-day of the Federal Criminal Justice system regarding the work on this theme, through operating a series of filters that are usual in accountability institutions. The research seeks answers to the following questions:

- What type of crime reaches the Federal Justice system and its courts of appeals?

- What is the pattern and profile of federal anti-corruption actions judged in the TRF4, Southern Brazil?

- What kind of corruption is dealt with in the TRF4, Southern Brazil (petty vs grand)?

- What are the competing crimes?

- What types of criminal organizations are found?

- What is the profile of the defendants of these corruption crimes in the Federal Justice?

Although this is descriptive research, the general hypothesis guiding this study is that the network of accountability institutions, although publicizing activities related to grand corruption, mostly fight and manage to take to the Federal Justice petty corruption, which involves criminals and low-level public officials.

Based on the literature on judicial decisions (Coacci, 2013; Oliveira \& Silva, 2005), the study adopted as object of analysis the criminal appeals produced by the TRF4 ${ }^{2}$ in the period from 2003 to 2016. The judgments were collected through jurisprudence research based on the term "corrupção" (corruption). The decisions referred to trials judged by the $7^{\text {th }}$ and $8^{\text {th }}$ chambers of the regional court (responsible for the Brazilian states of Rio Grande do Sul, Santa Catarina, and Paraná) $)^{3}$. Automatic content analysis was used to examine the data collected (Krippendorff, 1989), adopting dictionary

\footnotetext{
${ }^{1}$ We thank the commentators of the $9^{\text {th }}$ Latin American Congress of Political Science (ALACIP), the XXXI ALAS Congress, the Working Group "Jurists in society: political conflicts and the meanings of law," of the 41st ANPOCS Annual Meeting, and the anonymous reviewers of this journal.

${ }^{2}$ The courts of appeals that form the Brazilian Federal Justice are the 5 federal regional courts (TRFs): $1^{\text {st }}, 2^{\text {nd }}, 3^{\text {rd }}, 4^{\text {th }}$, and 5 th region. Other works that focus on the Federal Justice and the trials related to corruption cases work with a broader spectrum of institutions, analyzing, in addition to the TRFs, the superior courts: the Superior Court of Justice (STJ) and the Federal Supreme Court (STF) (Levcovitz, 2014). ${ }^{3}$ The 7 th and 8th TURMA of TRF4 were selected for the survey of jurisprudential research, since these are the collegiate responsible for judging criminal actions related to corruption.
} 
analysis (via key-categories), in WordSTAT software (Provalis Research, 2010), so the universe focuses on the judgments' content and the profile of the criminal prosecution of corruption cases.

The article is structured in 4 sections after this introduction: the first presents the theoretical framework on fighting corruption in Brazil through networks of accountability institutions, focusing on the results obtained with recent institutional change and interaction between the organizations. The second presents the method of dictionary analysis and the research strategies adopted. The third section focuses on the Federal Justice, in particular on the federal prosecution of corruption crimes, linking the literature debates with the findings of the TRF4 decisions on criminal appeals. Finally, the fourth section presents the final considerations.

\section{ACCOUNTABILITY INSTITUTIONS IN THE FIGHT AGAINST CORRUPTION}

Corruption is a central topic in research on democratic theory and political and institutional development related to debates on the public sphere, civil society, and the market (Warren, 2004). The importance of this social/political phenomenon is related to its influence over the governance and stability of political systems, over "the legitimacy of governments, the ability to govern, and even [the influence over] the general view of the population about the country" (Avritzer \& Filgueiras, 2011a, p. 7).

Corruption in Latin America, perceived as an element present in the history of many countries ${ }^{4}$, appears amid concerns of economic development and industrialization, imbricated in processes of change and institutional rupture for the adoption of democratic governments (Avritzer, 2008, p. 11).

The evolution of the theoretical debate about corruption can be observed as separated into two major waves: the first is the debate understood according to the modernization theory of the early twentieth century. The use of this theory is based on the belief that values and traditions affect the development of countries and their practices (related to political culture), so that the incidence of corruption in modern societies would be associated with the process of the society's evolution and its political institutions, as well as the degree of industrialization and development of the countries (Filgueiras, 2008). The second wave, from the 1980s onwards, is based on the belief that the curtailment of corruption happens in the market and in developing bureaucracy (Filgueiras, 2008, p. 304). The theoretical foundation is the neo-institutionalism of rational choice and the rent-seeking theory, for which the behavior of political agents aims at the maximization of their interests (Filgueiras, 2008, pp. 302-303).

\footnotetext{
${ }^{4}$ The analytical perspectives on the phenomenon can be synthesized in three major approaches: cultural (Power \& Taylor, 2011a) or historical (Avritzer \& Filgueiras, 2011a) tradition; functionalist approach; and the perspective of costs (rent-seeking theory) (Avritzer \& Filgueiras, 2011a). The first is one of the main approaches to corruption in Brazil, coming from the long tradition of studies on the public and private dilemma (Power \& Taylor, 2011a). The origin of the phenomenon would be related to the characteristics of Portuguese colonization in the formation of the Brazilian state and the development of bureaucracy (Avritzer \& Filgueiras, 2011a). "These culturally oriented arguments are a wise reminder that institutions can never be analyzed out of context" (Power \& Taylor, 2011a, pp. 10-11). The functionalist perspective, however, looks at corruption from the economic point of view. According to Avritzer and Filgueiras (2011a, p. 10), corruption can "fuel relations between government and businesspeople and pacify social cleavages, thus contributing to political stability." Finally, the cost perspective evidences the concern about economic development and the damage corruption causes in market economies (Avritzer \& Filgueiras, 2011a). Corruption can affect "investment and hamper economic development by introducing a system of collecting bribes within bureaucratic bodies that maximize the costs of corruption for citizens" (Rose-Ackerman, 1999, as cited in Avritzer \& Filgueiras, 2011a, p. 11).
} 
Over the past two decades, many countries have made legal and judicial reforms to strengthen the governments' democratic nature. The concept of accountability has been at the center of academic debate since the early 1990s, particularly in the literature on democracy, the rule of law, reforms, and judicial activism.

In Brazil, the milestones in this process are democratization and the drastic changes in the institutional design of the political, legislative, and judiciary systems, as well as the implementation of a state reform agenda during the 1990s, with the strengthening, autonomy, and independence of institutions of control in the country (Power \& Taylor, 2011b).

Brazil offers an important lesson about accountability not only because it is the fourth-largest democracy in the world and the largest in Latin America but also because of its remarkable institutional evolution over its most recent- and longest-experience with democracy. The development of accountability institutions in Brazil has been broad, dynamic, and continuous since the transition from authoritarian rule began in earnest in 1982. Several anticorruption bureaucracies, such as the Controladoria Geral da União (CGU) [Office of the Comptroller General], an executive auditing body, have been created out of whole cloth. Others, such as the Ministério Público [Public Prosecutor’s Office] prosecutorial service and the Federal Police, have been transformed to such a degree that they no longer resemble their predemocratic incarnations (Power \& Taylor, 2011a, p. 4)

Praça and Taylor (2014) analyze the evolution of state capacity for accountability created in Brazil from a complex and interdependent network that includes bureaucracies focused on supervision the Office of the Comptroller General (CGU) and the Federal Court of Accounts (TCU); research - Federal Police; and sanction - Public Prosecutor's Office at the federal level (MPF) and the courts. Avritzer and Filgueiras (2011a) add to these mechanisms of administrative-bureaucratic and judicial control, a third, which they denominate non-state public control. While the first authors point out that the creation of interaction capacity between the different agencies (regarding rules, routines, roles, and resources) promoted a strong institutional change (Praça \& Taylor, 2014), the latter warn of the importance of the third mechanism, saying that "the lack of integration of these three forms of controlling against corruption unleashes a growing process of delegitimation of politics" (2011a, p. 16) ${ }^{5}$.

\subsection{The justice system in the fight against corruption: judicial accountability}

Corruption as a social and political problem has triggered a great social outcry for the moralization of politics, a moralism that "promotes a shift from the political to the legal order, particularly in the criminal dimension. This shift occurs because we transfer to the law the capacity of control over the action performed by the public authority" (Avritzer \& Filgueiras, 2011a, pp. 8-9).

In modern representative democracies, courts have played a central role as mechanisms of popular control and societal accountability. They enable individuals and groups to use litigation to advance

\footnotetext{
${ }^{5}$ Avritzer and Filgueiras (2011a, pp. 8-9) believe that "the problem of corruption in Brazil should be thought not in the dimension of moralism and criminal logic, but in terms of democratic controls."
} 
and protect their rights and interests (Peruzzotti \& Smulovitz, 2006; as cited in Gloppen, Gargarella, \& Skaar, 2004). Courts are central to the horizontal accountability system because they support the relationship between state actors and the Constitution. Acting on its responsibility to protect the law and the Constitution, the courts protect the government's channels of vertical control, counting on other institutions and agencies more specialized on horizontal accountability functions.

Gloppen et al. (2004, p. 17) reinforce the importance of the courts in new democracies "in which courts can be more successful in rendering government accountable for rights protections by initially confining themselves to narrow rule of law based invalidations of executive action, particularly by subordinate or local officials, in which the courts may present themselves as allies rather than opponents of the law-making and/or highest executive authorities. The two-step nature of 'rule of law' would facilitate subsequent successful judicial movement from a more modest to a more activist protection of individual rights.

Brazil has advanced in the field of judicial accountability policies and fights against corruption, by "increasing the participation of the judiciary and the MP [Public Prosecutor's Office] in the control of the acts of the executive and legislative branches" (Arantes et al., 2010, p. 135). The increase in participation is directly linked to a movement to strengthen the institutions of the justice system, mainly by providing institutional independence to the MP and autonomy to the Federal Police (PF) (Arantes, 2011b).

As for the MP, it is possible to observe an increase in the institution's prerogatives and powers to act both in the civil (defense of diffuse and collective rights, through civil lawsuits) and in the criminal (mechanisms of investigation and criminal instruction) areas.

The judicial control in the fight against corruption in Brazil can be performed through the Administrative Improbity Law (Law 8429/1992). This legislation was an innovation in the treatment of corruption by judicial institutions because it "significantly expanded the MP's role as the horizontal accountability body in the Brazilian political system [...] promoting a faster and more decentralized way of fighting corruption" (Arantes et al., 2010, p. 143). This, however, was not effective.

The inefficiency of the dealing with corruption cases through the legislation on administrative improbity, together with the institutional strengthening of the MP and the PF and the increase in the number of police operations, led to the shift from civil to criminal treatment, i.e., the treatment of corruption as a crime became the main field of action (Arantes, 2011b).

This movement of "recent resumption of the treatment of corruption as a common crime, with police operations, carried out with the participation of members of the MP and endorsed by judges" aims to "reduce impunity and obtain faster and concrete results against politicians and public officials" (Arantes et al., 2010, p. 143). This treatment means that the defendant may be arrested, facing "imprisonment from one to eight years, in addition to the loss of their position and payment of a fine" (Arantes et al., 2010, p. 143).

Arantes (2011a) argues that the first shifts from the civil to the criminal area and from the state to the federal level - can be explained by the institutional design capable of providing more effective results in the criminal and federal spheres, such as the greater articulation and interaction among police chiefs, prosecutors, and judges (Arantes, 2011a). The increase in the connection among these actors can be explained by the endogenous motivation and by the commitment of organizations to 
increase the effectiveness of their actions, such as the MP's operation under the standard of political voluntarism (Arantes, 2011b, p. 187).

The articulation between accountability institutions, primarily through the collaborative work of the $\mathrm{PF}$ and the $\mathrm{MP}^{6}$, are evidence of a necessary integration movement for the adequate operation of the mechanisms to fight corruption (Arantes, 2011a, 2011b).

If the control over the public administrators' conduct and the fight against political corruption have experienced significant growth in recent years, not only are the institutions involved more active, but the triangular articulation between them (Judiciary, MP, and police) has intensified. This is perhaps the main novelty within the judicial accountability system in Brazil today (Arantes et al., 2010, p. 145).

The interaction between the Judiciary, MP, and PF is essential for anti-corruption mechanisms since the institutional arrangement is complex and the judiciary only intervene when activated (Arantes, 2011b). The importance of this study is to contribute to the literature on fighting corruption in Brazil, which rarely addresses the role of the courts, which are sometimes considered the bottleneck and sometimes as having a central role in actions against corruption. The study advances dedicating special attention to the role of the Federal Justice in the articulation with other horizontal accountability institutions operating in the country.

The work of Aranha (2017) is one of the rare studies addressing accountability institutions. The author maps their operation through a longitudinal flow analysis in a group of cases, determining, since their beginning, the percentage of cases that progress to the subsequent stages. Although common in the analysis of other criminal phenomena, this method is still little used by anti-corruption studies.

The author reinforces previous positions that, in spite of the improvement of the horizontal accountability institutions since the re-democratization in Brazil, with more autonomy of the MP, more resources and personnel for the $\mathrm{PF}$, and the establishment of auditing and corruption prevention as the main mission of the Office of the General Comptroller (CGU), none of these institutions respond alone or concentrate all steps that involve the accountability cycle, which includes monitoring, investigation, and sanctioning. The credibility and effectiveness of the network thus depend on the quality of the relations established between the different components of the system.

It is in this context that the importance of the judiciary is highlighted. The judiciary is a reactive institution whose effectiveness in the accountability process depends on the previous organizations, especially on the quality of the cases sent by the MP at the federal level (MPF). The judiciary represents, therefore, the last link between this series of relationships among institutions (Aranha, 2017, p. 9):

The primary responsibility of the Brazilian Federal Justice is to judge cases involving the Union and foreign entities, international treaties and crimes against the financial system and the economic order. Its role is to decide on the responsibility of the defendants and impose legal sanctions on politicians involved in corruption practices.

\footnotetext{
${ }^{6}$ It is necessary to stress the importance of the use of other instruments and mechanisms by the PF and MP in the fight against corruption and organized crime, such as the use of wiretapping, remand (Arantes, 2011b), and search and seizure warrants, as effective means to produce and obtain evidence (Arantes et al., 2010).
} 
Judicial control of corruption is a type of control exercised in the legal sphere. It is a form of state control that starts from a formal concept of public interest placed within the scope of the legal system. The assumption is that the judiciary must control the Public Administration, given a system of laws and regulations interpreted observing the jurisprudence. "Judicial control is exercised in the field of law, according to the neutrality and universalization resulted from the legal interpretation of codes, statutes, and regulations" (Avritzer \& Filgueiras, 2011a, p. 18).

Although there is a defense of the effectiveness of corruption criminalization and judicial control, some authors question the fact that "the criminalization of corruption contributes to empowering judicial institutions, shifting political representation from the parliament to the justice system" (Avritzer \& Filgueiras, 2011a, p. 26). This movement privileging the judicial institutions reduced the capacity of "public control exercised by civil society and emphasized control within the state apparatus, particularly in the judiciary system" (Avritzer \& Filgueiras, 2011a, p. 28).

Notwithstanding the defense that the problem of corruption should be thought outside the criminal area, we believe it is necessary to analysis how the courts address the criminalization and punishment, and what the prevalent types of cases are

If literature and the media privilege the great scandals, will this kind of occurrences be the focus of the justice system's daily routine regarding fighting corruption? In this study, the proposal lies precisely in understanding this context, observing the last link in the chain - the Federal Justice. However, before turning to empirical research, it is crucial to establish a concept of corruption, exploring its forms and the normative treatment given to these practices.

\subsection{The crime of corruption: concepts, types, and judicial practices}

The literature on corruption points to the strong negative correlations between economic growth and corruption, damage to democracy, and governance institutions, i.e., the monetary and institutional effects of corruption (Carson \& Prado, 2014).

Transparency International defines corruption as "the abuse of entrusted power used for private gain” (Transparency International, n.d.). In this study, we highlight two forms of corruption. 'Grand corruption' is the practice presenting high-level abuse that benefits few at the expense of many, causing severe and widespread harm to individuals and society. This form of corruption is likely to remain unpunished. Another form is petty corruption which involves practices such as the abuse of power by public officials in their interactions with ordinary citizens, who are often trying to access basic goods or services in public facilities such as hospitals, schools, police stations, and other agencies (Transparency International, n.d.a).

Transparency International also offers a concept for political corruption, understood as "a manipulation of policies, institutions, and rules of procedure in the allocation of resources and financing by political decision-makers who abuse their position to sustain their power, status, and wealth" (Transparency International, n.d.b).

As for the participation of the state bureaucracy in corruption crimes, we observe that this is not a uniform phenomenon, being "found among low-level bureaucrats and involve relatively modest sums ("petty corruption") or stretch to the highest levels of government here officials wield significant influence and authority over major assets and revenues ("grand corruption")" (Carson \& Prado, 2014, p. 4). 
Along with definitions of corruption, it is essential to conceptualize criminal organizations by the degree of correlation between the two practices. Brazil adopts the definition of organized crime coined at the United Nations Convention against Transnational Organized Crime, which is a generic concept that considers organized criminal groups as a "group structured by three or more people, long existing and acting with the purpose of committing one or more serious infractions," or "with the intention of obtaining, directly or indirectly, an economic benefit or other material benefit" (Brasil, 2004, as cited in Mingardi, 2014, p. 318). By this definition, one confuses organized criminal group with forming a gang.

To define the concept of organized crime, it is crucial to consider some attributes, such as de facto hierarchy; link with the State; division of labor; planning and forecasting of profits; the power of intimidation; law of silence (Mingardi, 2014).

Mingardi (2014, pp. 320-321) presents a typology with three classifications. The first is 'traditional' where 'there is the figure of the 'godfather' or 'master', who is the patron and directly responsible for the new member." The second is 'business', marked by transposing business methods to crime while leaving aside any remnants of concepts such as honor, loyalty, and obligation. It brings together specialists who work as a team to perform a given activity, in relationships that do not go through family or ethnic ties, where everyone has a profession, and money laundering and vehicle theft and receiving are standard practices. Finally, the third classification is the endogenous model, where the organizations are the result of a "criminal group that is born within a legal organization," usually the State apparatus, and it is also formed within private companies. These organizations start with the participation of members who already commit "crimes of opportunity" and organize by creating a chain of command and division of tasks. Criminal organizations can combine characteristics of the classifications presented above, and the most common are the traditional and business type of organizations.

Traditional concepts of corruption argue that it should be "considered in terms of legality and illegality, not morality and immorality, taking into account the differences between social and normal legal practices and the diversity observed in behavior assessment in the private and public sector" (Pasquino, 2010, p. 291-292). However, it is essential to note that in Brazil, crime and corruption exist in a spectrum whose boundaries are often culturally, rather than legally, determined (Macaulay, 2011, p. 220).

Macaulay (2011) asks, based on Misse's concept of political merchandise ${ }^{7}$, whether organized crime corrupts state agents or simply co-opts them to be commercial partners, through extortion and privileged access to information about the police and investigations. A political and economic framework emphasizes the continuum between different types of illegal activities and how the players combine interests among the spectrum of political clientelism, corruption, underground economic market, smuggling and criminal violence (Macaulay, 2011, p. 220).

\footnotetext{
${ }^{7}$ The concept of political merchandise is related to the understanding of the exchange processes arising from the relationship between political and economic power, a decision-making process related to the notion of political calculation (Misse, 2014). For Misse (1997, as cited in Misse, 2014, p. 200), political merchandise is "any good that combines political costs and resources (expropriated or not of the state) to produce a political or economic exchange value." On a more concrete perspective, this concept is usually associated with "corruption," though it is not limited to that. The relationship of power and exchange from the notion of "political merchandise" comes from the state and from market relations, the interaction between public and private (Misse, 2014, p. 200) and its political grammars. The production of political merchandise is usually criminalized in different articles of the criminal code, but the more or less tolerance is observed that allows the wide circulation of illicit goods, including political 'goods,' which defines an area of illegality whose punitive sanction tends to turn into a political merchandise (Misse, 2014). According to the author, the use of the concept in studies on corruption opens possibilities for analysis to the "different degrees of tolerance in the process of incrimination, largely associated with the exchange of political merchandise at various levels of the state and of the crime, which is organized as business and as a center of power" (Misse, 2014, p. 202).
} 
Observing the particularities of the concept of corruption in Brazil, the degrees of tolerance in the process of incrimination, and the possibilities of response the criminal justice system may apply to the cases, it is important to discuss the concept of criminal selectivity. This term refers to "how and why the state privileges the persecution of certain conducts or certain groups of criminals, or is tolerant of other conduct and social groups" (Sinhoretto, 2014, p. 401), due to the inequality of the justice system, both in access to the right to a fair hearing.

Based on this theoretical reference, the next section presents the methodology adopted.

\section{METHODOLOGY: TEXT MINING AND CO-OCCURRENCE ANALYSIS (WORD CO-OCCURRENCE NETWORK)}

Studies on corruption and operation of the network of accountability institutions share the same problem: how to measure corruption in a given country or context? Most of the corruption indicators are measures of population perception about formal and informal institutions and corruption (Levcovitz, 2014).

In order to map the role of the Federal Justice in judging cases involving the crime of corruption, this research reproduced the data collection technique used in the study on the judgment of social policies in the Federal Regional Courts (TRFs) (Wood \& Geliski, 2017), which was based on the court's decisions. In this research, we used the consultation of jurisprudence, adopting the word "corrupção" (corruption), to understand the operation of the 7th and 8th chamber of the TRF4, dealing with criminal justice, from 2003 to 2016.

The universe of this research comprises decisions available in the jurisprudential research platform of TRF4 (Justiça Federal da $4^{a}$ Região, n.d.), and is representative of the decisions made available, i.e., it may not cover all the decisions.

As in Levcovitz (2014), the findings indicate the judicial demands and the social contexts (characteristics of the adjudicated fact), and face the same challenge as the cases of corruption, regarding measurement. As for the nature of the database prepared for this research, it was composed of unstructured data (texts), so that the set of judgments collected from the chambers of TRF4 are the corpus of analysis.

Because they are text data, automatic analysis of the content was carried out, by forming a dictionary ${ }^{8}$ with the terms according to their occurrence. The method of content analysis, in this case from the examination of the content of the decisions and the analysis of the narratives, considers the texts as units of information with meanings and constituent elements, as well as products of the social space (context) of the document's production (Krippendorff, 1989). In this research, the set of decisions of the TRF4, collected through the jurisprudential research, forms the corpus analyzed (unit of analysis) and the court is the context.

In order to know the day-to-day operation of the Federal Justice, the dictionary method was applied, mapping and establishing categories for the content of the decisions. The categories considered the types of crimes judged, associated with the search entry "corrupção" (corruption); the relations between different crimes; the profile of the actors and defendants of the lawsuits; and the logic of operation of the Judiciary as the last institution working in the network of accountability institutions.

\footnotetext{
${ }^{8}$ The dictionary is presented in Box A of the Appendix
} 
In the dictionary method, "dictionaries use the rate at which key words appear in a text to classify documents into categories" (Grimmer \& Stewart, 2013, p. 8). This technique of analysis requires certain knowledge about the documents analyzed since the dictionary and its categories must be in line with the empirical context (TRF4) and the specific use of certain terms in the texts (Grimmer \& Stewart, 2013, p. 8). In this research, the first step was to map the words according to the frequency they occur in the content and reports of judicial decisions. The map subsidized the organization of the terms forming the dictionary, based on the crimes identified in the texts. The dictionary was formed with 54 keywords corresponding to criminal types provided in 10 federal laws: Brazilian Criminal Code; Brazilian Traffic Code; Statute of Disarmament; Law on Abuse of Authority; Law on Crimes against the Tax System; Law on Drugs; Law on Money Laundering; Law on White-collar crimes; Law on Environmental Crimes; and Law on Tax Evasion.

Crimes were analyzed based on the words co-occurrence, i.e., in the identification of links among key-concepts highlighting situations in the text where there is a higher incidence of words associated with each other. Co-occurrence analysis makes it possible to construct word networks (Verd \& Lozares, 2014), which help to visualize patterns of text construction, in this case, helping to visualize crimes (terms) that are closely associated with each other. The corpus of the research was submitted to traditional qualitative analysis, interpreting the findings in light of the literature on the operation of networks of accountability institutions and the dynamics of criminal prosecution.

\section{CRIMINAL PROSECUTION AT THE FEDERAL REGIONAL COURT IN THE SOUTH OF BRAZIL}

The importance of looking at the courts' performance lies in broadening the analysis of the spectrum of the operation of the network of accountability institutions beyond the Federal Police (PF) and the Ministério Público (Brazilian Public Prosecutor's Office) (MP). This importance is reinforced by Power and Taylor's (2011a, p. 19) approach, which emphasizes that "the federal judiciary and the electoral courts are the recipients of much of the Ministério Público's effort." Since MP and PF are central figures in federal criminal prosecution, especially regarding the fight against corruption, looking at the judgment of the courts of appeal allows to identify this general scenario and produce information about what is punished and who is punished, as well as whether the major corruption cases reported in the media represent the judiciary's agenda setting.

The Brazilian judiciary is largely reactive, and its effectiveness in the accountability process relies heavily on proximate institutions, and especially on the quality of cases forwarded to it by the Ministério Público [Brazilian Public Prosecutor's Office], with contributions from antecedent institutions such as CPIs [parliamentary inquire committee] and the Federal Police (Power \& Taylor, 2011a, p. 20).

Based on the examination of the judgment of appeals and other instruments (such as habeas corpus and writ of mandamus) resulted from trials conducted in the court of appeals TRF4, which are originated due to the Federal Judiciary activity in the three Brazilian southern states, the research accessed 3,401 judgments made between 2003 and 2016. The study of the content of the judgments conducted by the $7^{\text {th }}$ and $8^{\text {th }}$ chambers of the court indicates that there is an increase in the number of cases distributed to the TRF4 over the last 13 years (see Graph 1). 


\section{GRAPH 1 UNIVERSE OF JUDGMENTS IN THE COURTS OF APPEAL TRF4 ON THE TOPIC "CORRUPTION"}

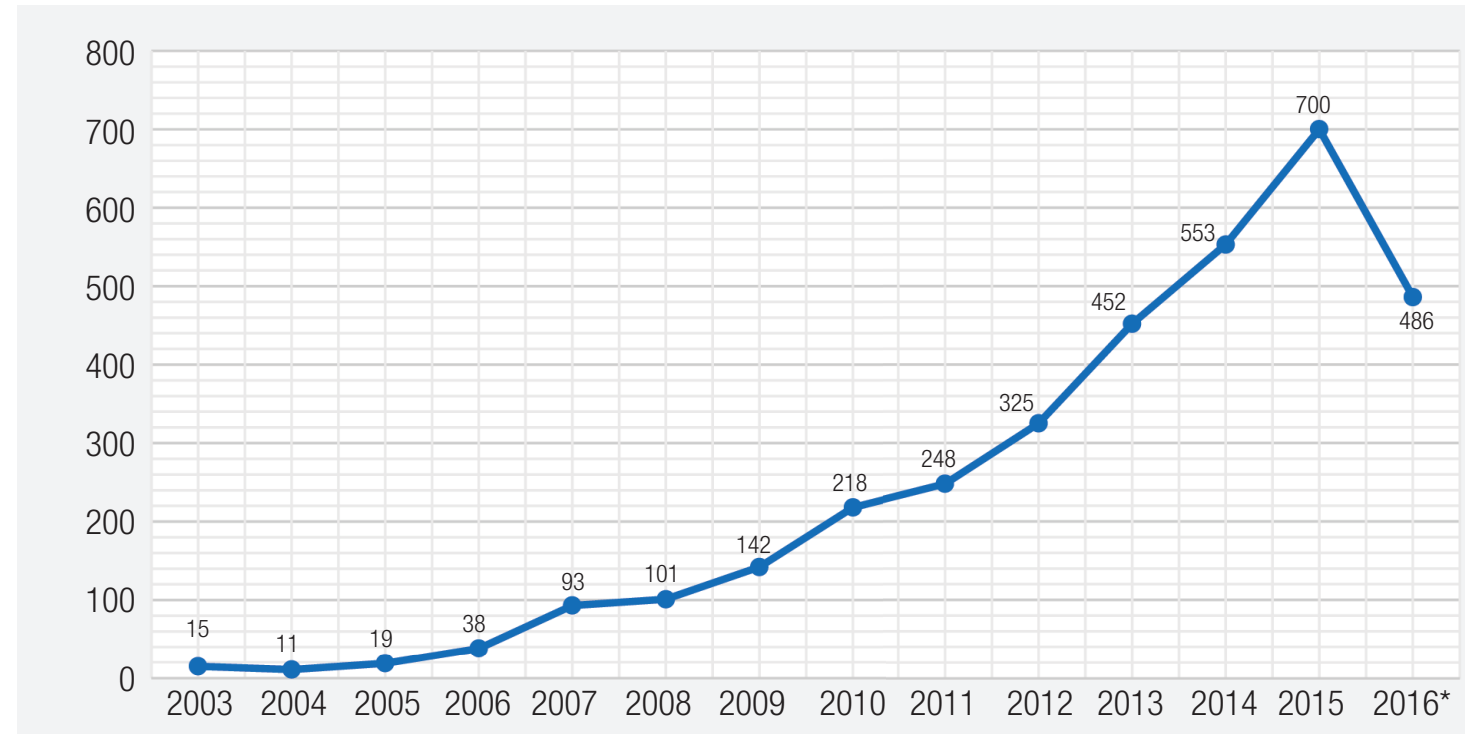

* 2016: the study collected and analyzed judgments made until November 2016.

Source: Elaborated by the authors.

This growth corroborates the findings of Levcovitz (2014), who examined the Federal Justice (non-specialized courts), the TRFs, the Superior Court of Justice (STJ), and the Federal Supreme Court (STF) and identified a significant increase in cases of corruption crimes in the Federal Justice (both in the courts of appeal and in superior courts) in the period from 1991 to 2010. This result was a "surprising growth of approximately [10] times from 50 to 500 cases judged annually" (Levcovitz, 2014, p. 28). On the other hand, works such as Costa and Oliveira (2016, p. 161) point out that rarely do criminal cases in Brazil come from "criminal investigation work. In most of the cases reported there was no effective criminal investigation work because the accused were caught in the act (53.7\%) or were already arrested for other crimes (6.3\%)."

Based on these two scenarios - the first, a scenario of criminal prosecution cases without proper instruction during investigation; the second, a context of growth in the number of criminal decisions on cases of corruption in the Federal Court - it is necessary to observe the activities of the Judiciary, by examining its judgments, in order to understand the dynamics of processes related to corruption crimes and whether they reproduce these two scenarios.

Looking at judicial decisions as a source of research is a strategy that expands the studies on corruption, taking them beyond the traditional indicators related to perception, based on surveys. Levcovitz (2014) argues that it is difficult to measure the real occurrence of corruption since most cases correspond to what the author calls "hidden numbers," i.e., cases that have never been or will never be discovered (Levcovitz, 2014, p. 28). Thus, our analysis is limited to the scenario of federal criminal prosecution in the Southern region and not the scenario of the reality of cases of corruption in the states.

The analysis of the co-occurrence and frequency of the crimes found in our database shows that the corruption-related criminal types that are more present in the day to day of the federal justice are 
smuggling and improper clearance. Using Transparency International's classification of corruption (petty, grand, or political corruption), the prevalence of petty corruption is evident.

Graph 2 helps to visualize the preponderance of these types of crime, even though there are other types more disseminated in the media, such as "lavagem de dinheiro" (money laundering), "fraude" (fraud), and "estelionato" (larceny). Crimes that involve violent urban crime or violent crime are much less recurrent in the Federal Justice, such as "tráfico internacional de entorpecentes" (international drug trafficking), "tráfico ilícito de entorpecentes" (drug trafficking), "Associação para o tráfico de drogas" (association with drug trafficking), "roubo qualificado" (aggravated robbery), "extorsão mediante sequestro" kidnapping with ransom, and "tentativa de homicídio" (attempted murder).

\section{GRAPH 2 CO-OCCURRENCES AND FREQUENCY OF CRIMES IN THE DICTIONARY ANALYSIS 9 (TERMS ANALYZED IN BRAZILIAN PORTUGUESE)}

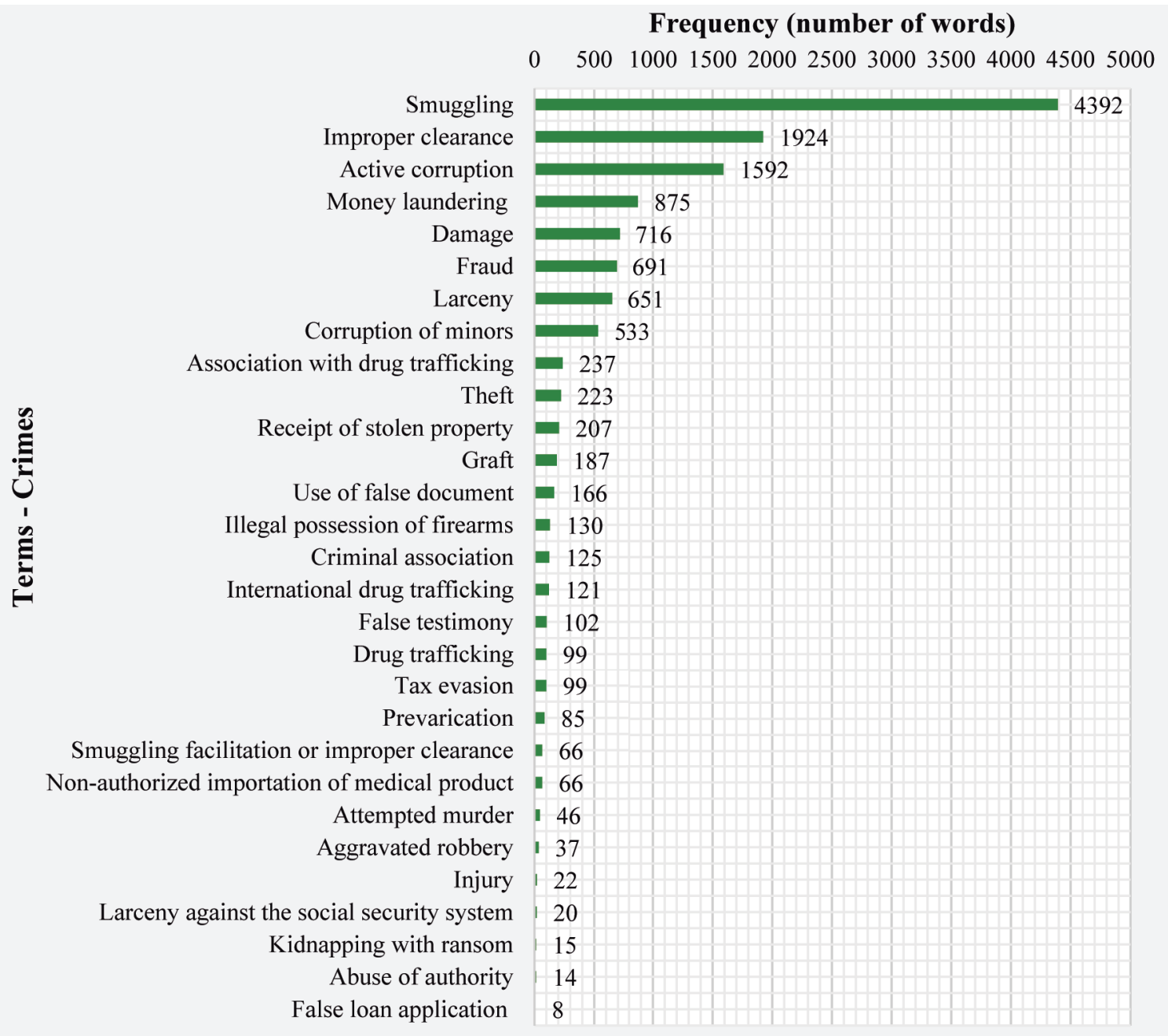

Source: Elaborated by the authors.

\footnotetext{
${ }^{9}$ The frequency ratio of words is shown in Table B, in the Appendix of this article.
} 
As for the legislation used in trials held in the TRF4 courts, the prevalent norm is the Brazilian Criminal Code, which typifies crimes against the public administration, followed by specialized legislation, such as the Law on Drugs, Law on Money Laundering, providing on the crime of "lavagem ou ocultação de bens, direitos e valores (laundry or concealing of assets, rights, and values); Law on White-collar Crimes - particularly the crimes of "evasão de divisas" (foreign exchange evasion), and "obtenção de financiamento mediante fraude" (false loan application) -, in addition to other laws such as Brazilian Traffic Code, Statute of Disarmament, Law on Abuse of Authority, Law on Crimes against the Tax System, Law on Drugs, Law of Environmental Crimes, and Law on Tax Evasion (Graph 3).

\section{GRAPH 3 LEGISLATION USED IN THE TRIALS}

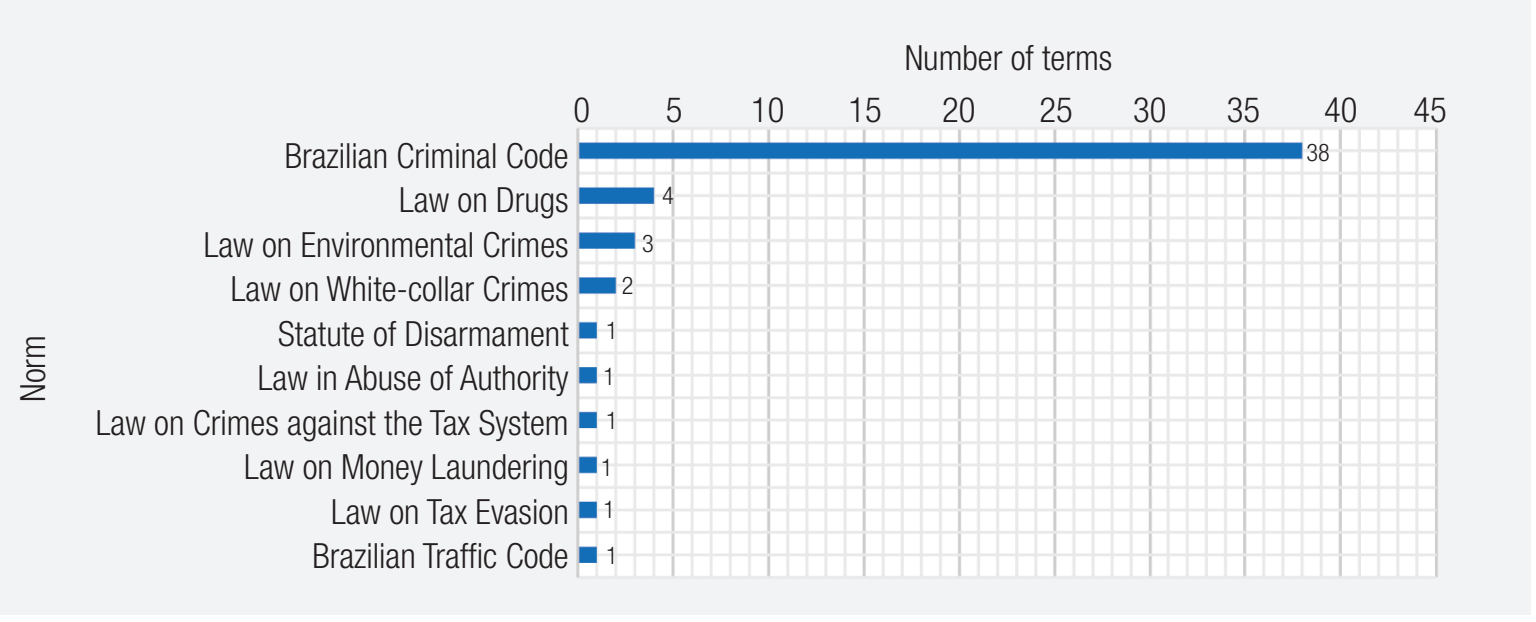

Source: Elaborated by the authors.

When pursuing this study's objective of establishing the profile of the cases judged considering the profile of defendants and the type of crime - using qualitative analysis based on the content of the judgements - it was possible to observe that most of the crimes judged refer to crimes committed by low income people and street-level bureaucrats, indicating that this is the most recurrent crime regarding corruption, but also indicating the effects of the selectivity of the Criminal Justice System (Sinhoretto, 2014) in pursuing lower-tier conduct in contrast to large-scale corruption cases.

Regarding references, Figure 1 illustrates the prevalence of smuggling offenses, associated with improper clearance, followed by active corruption.

The qualitative analysis shows that a significant part of the content of the judgment texts refers to "contrabando" (smuggling), particularly cigarette smuggling, with about 4,000 results. Cigarette smuggling coming from Paraguay to be distributed throughout Southern Brazil is the most frequent occurrence described. To have a better idea of the characteristics of this type of crime, the criminals obtain gains of $\mathrm{R} \$ 2,000$ per transport of cigarettes. It should be noted that, despite the apparent low socioeconomic profile of the defendants, more than half of them use the services of private lawyers (62.3\%), and the others use the Public Defender's Office. This percentage can be confirmed by other 
studies on smuggling and border crimes as to the organized nature of this criminal practice. When considering that such crimes occur with reasonable levels of organization, the concepts of criminal organization exposed in the theoretical framework indicates that these organizations are similar to traditional and business enterprises and cannot be characterized as a corporate criminal organization as suggested by Mingardi (2014).

\section{FIGURE 1 CLUSTER BASED ON THE CLOSENESS OF CRIMES IN THE COURT'S DECISIONS (ELABORATED IN BRAZILIAN PORTUGUESE)}

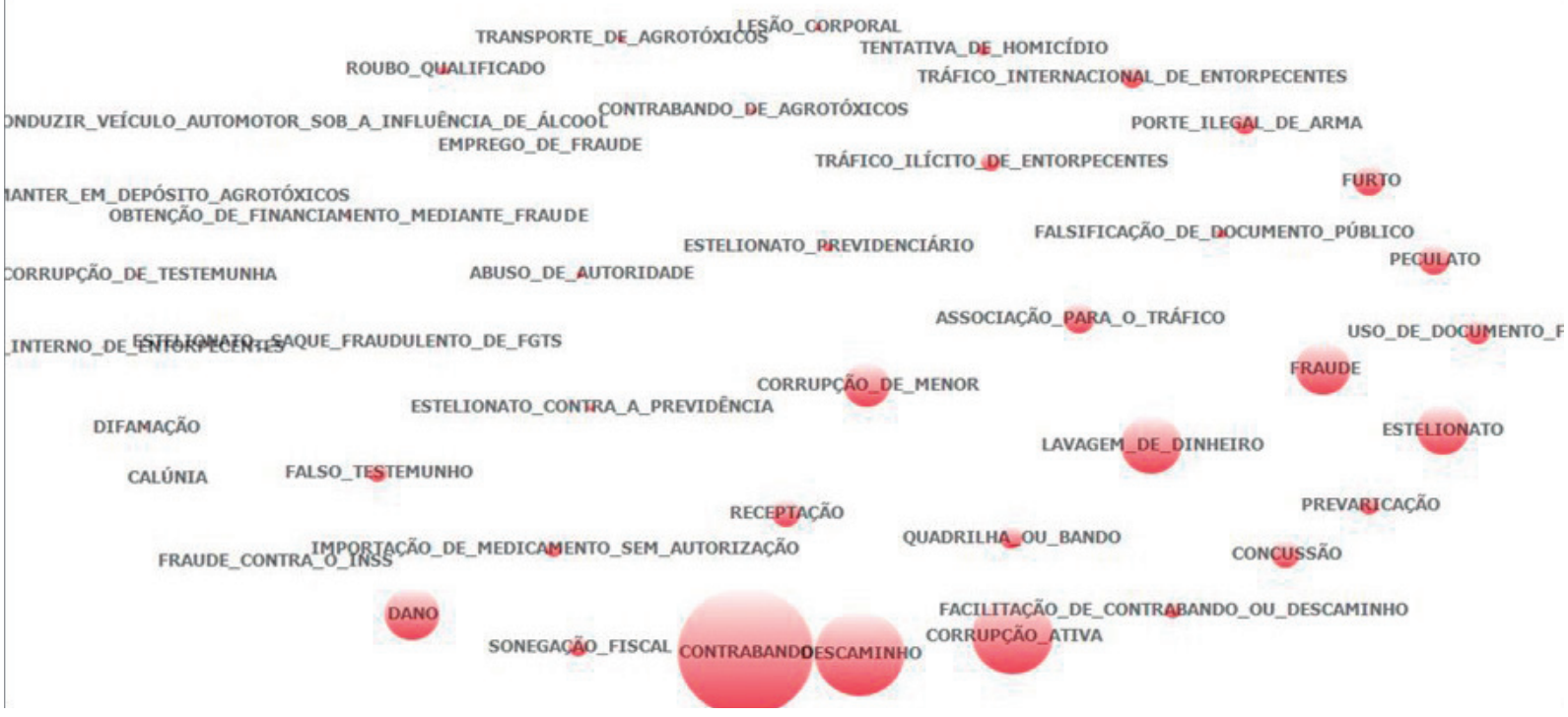

Source: Elaborated by the authors.

As for the specific crime of smuggling cigarettes, it is possible to refer to Misse's concept of political merchandise (2014). Smuggling falls within the scope of

[...] social practices of countless workers ${ }^{10}$, engaged in the different activities originated by the relations established in the Paraguayan market [...]. Within a dynamic universe, thousands of social subjects vie for and articulate themselves around diverse interests, the struggle for the survival of some divides the same territory with the ambition of others who seek high and easy profit (Cardin, 2012, p. 208).

\footnotetext{
10 "Regulated practices are mixed with irregular ones in a relationship of interdependence, and the different subjects involved in the activities derived from trade with Paraguay are leveled and observed by the media and by the public power in a generalized way. But this is due to the fact that the organization of trade and logistics for the operation of shopping tourism; the routine of the "sacoleiros" (people that come and go buying merchandise in Paraguay and selling in Brazil); and the smuggling of firearms and drugs, have a number of points of intersection. The shops and sellers that make the goods available in Ciudad del Este, Paraguay, and the "freteiros" (people hired to enter with the purchased goods in Brazil) are at the service of both tourists and buyers (the "sacoleiro,"and "laranja" [straw-man] for example). The difference between serving tourists and buyers by entering with their products in the country is in the quantity of products acquired by who hired the "freteiro" (Cardin, 2012, p. 214).
} 
The results showed five patterns regarding the incidence of criminal types. They are listed below in ascending order according to the co-occurrence index and links: 1) the crime of "contrabando" (smuggling), linked to the crimes of "descaminho" (improper clearance) and "corrupção ativa" (active corruption). When associated with "corrupção passive" (passive corruption), the crime of "contrabando" (smuggling) is linked to "concussão" (graft); 2) there is a link between the crimes of "sonegação fiscal" (tax evasion), "lavagem de dinheiro" (money laundering), and "evasão de divisas" (foreign exchange evasion); 3) the crime of "receptação" (receipt of stolen property) is related to the "uso de documento falso" (use of false document) and "porte ilegal de arma" (illegal possession of firearm); 4) the crime of "apropriação indébita" (misappropriation and falsification of public documents); and, finally, the pattern related to 5) the crime of "associação para o tráfico de drogas" (association with drug trafficking) (see Figure 2).

\section{FIGURE 2 WORD NET OF THE CRIMES CO-OCCURRENCES IN COURTS DECISIONS (ELABORATED IN BRAZILIAN PORTUGUESE)}

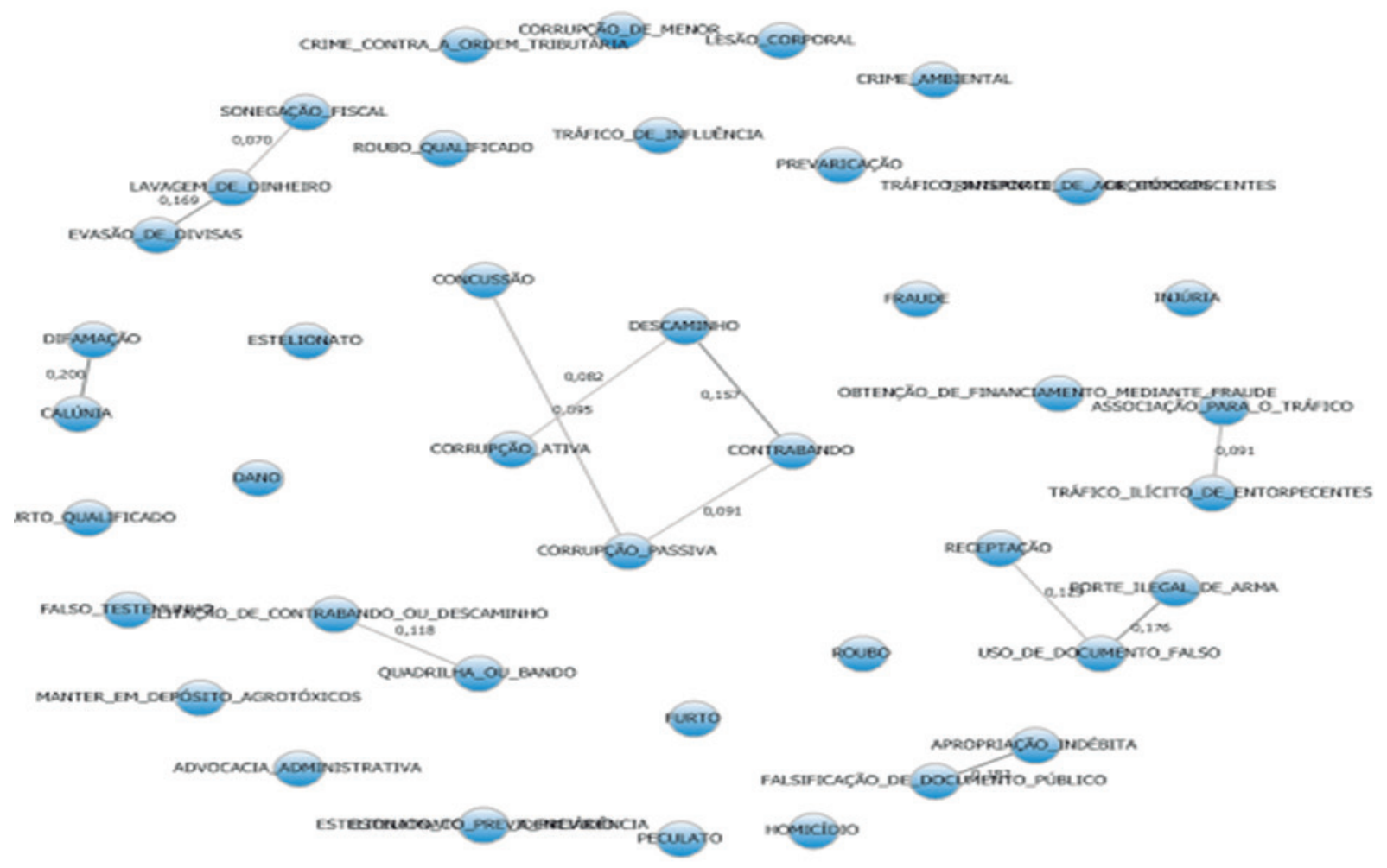

Source: Elaborated by the authors.

Among the five patterns of relationships seen in the word network, the nodes are crimes (words), and the ties are the chances that a word appears in the same segment of text. The first pattern of relationships illustrates the logic of integration among the terms for one of the main crimes identified 
in the activities of the Federal Justice, "contrabando" (smuggling). The relationship among words shows the way to access a street-level bureaucrat during the practice of "corrupção ativa" (active corruption) and "descaminho" (improper clearance), operated by an individual, toward the crime of "contrabando" (smuggling) - which is operated within the scope of transnational crime. The bureaucrat, in this case, incurs in the crimes of "corrupção passive" (passive corruption) and "concussão" (graft).

It is possible again to discuss the categories of organized crime (Mingardi, 2014) and political merchandise (Macaulay, 2011; Misse, 2014), as well as the degrees of corruption or co-optation of public agents by players involved in illegal activities. When performing a ethnographic analysis in a context of borders (where the crimes of smuggling and improper clearance are more likely to occur), Cardin (2012, p. 215) points out that

[...] the relationship between the routine of the "sacoleiros" and the smuggling of firearms and drugs is more delicate. Both activities have similar organization and often occupy the same distribution space. This situation allows generalization and a primary condemnation of any social practice linked to the illegal transportation of goods from Paraguay, regardless of the type of merchandise. Thus, the smuggler responsible for the negotiation of illicit products (such as drugs) is not separate from those who work transporting and reselling computer peripherals without payment of due taxes. In other words, legally distinct activities end up being equated in daily life by the media and by the form of combat exercised by the Revenue Service and Federal Police.

Reinforcing the above understanding, we find that in judgments, despite crimes of low pecuniary value, the principle of insignificance or trifle rarely applies (usually by the quantity of seized goods on average 400 cigarette boxes are seized each time the defendant is caught in the act), although the content of the judgments do discuss this principle.

Following the indication of recurrence and judicial selectivity in crimes perpetrated by low-level offenders, we found more than 1,000 records of the use of the term "vulgo" (meaning "so-called" in Brazilian Portuguese) in the courts' decisions, when referring to defendants. This term is characteristic of large-scale crimes (except for some large criminal operations, such as the well-known Car-Wash Operation and the lists of politicians benefited with bribes paid by the company Odebrecht). The use of "vulgo" is linked to crimes such as bank theft and robbery, criminal organizations engaged in theft of jewelry deposited in banking institutions with pledge agreements; gold intermediation; illegal money exchange operations; drug trafficking; counterfeit currency - production, storage, distribution, and receipt; receipt of stolen property, and larceny. As for the use of the term "laranjas" (straw-man) (with about 200 results in the analysis), most crimes refer to: fraud against the national social security system - such as undue labor claims; smuggling and corruption of public agents; lending of a bank account to be operated by criminal organizations; carrier transporting drugs; and receipt of weapons for use in a criminal organization.

Regarding the profile of bureaucrats involved in corruption, the reference to public agents (i.e., civil servants and public officials) is found in more than 1,000 results. The majority of them are street-level bureaucrats (Lipsky, 2010), such as police officers (federal police); border agents of the Internal Revenue Service; professors of federal educational institutions; inspectors related to activities of labor, social security, and the National Institute of Colonization and Agrarian Reform (INCRA); 
agents of the Ministry of Fisheries and Agriculture, and public officials working in large state-owned enterprises (such as Petrobras and Eletrobras). On a smaller scale, it is possible to find representatives of the middle and upper echelon, such as police chiefs, judges, and prosecutors.

The literature points to critical institutional changes in the design of the horizontal network of accountability institutions (Arantes et al., 2010), which turn it into a more coordinated network, consequently increasing the effectiveness of the fight against corruption through criminal prosecution (Arantes, 2011a, 2011b). These changes corroborate Aranha's analysis (2017) that the credibility and effectiveness of the network depend on the quality of the relations established among the different components of the system. However, it was possible to observe a great distance between the cases of grand corruption recently dealt with by the Criminal Justice system and its apparatus, and the immense majority of cases of petty corruption that consume most of the time in the day-to-day activities of the federal courts in the South of Brazil.

It is in this narrower scenario of grand corruption that new practices of criminal investigation and instruction stand out, through the use of telephone interception, denounces, and leniency agreements. The adoption of these new practices begins to appear timidly in the corpus of the research from 2013, considering that denounces and leniency agreements gained space in the processes from 2015 onward.

\section{GRAPH 4 NEW PRACTICES OF INVESTIGATION AND CRIMINAL INSTRUCTION}

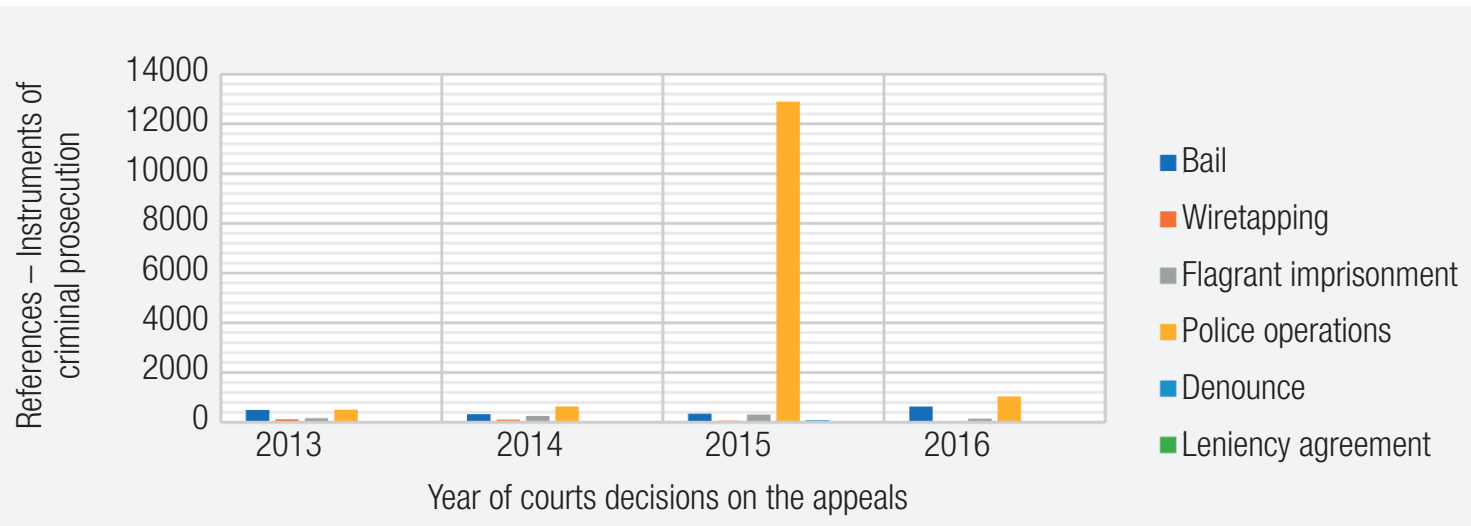

Source: Elaborated by the authors.

We found about 300 results related to telephone interception, used precisely in situations of grand corruption involving the following crimes: "tráfico internacional de entorpecentes" (international drug trafficking); "fraude ao INSS" (Larceny agains the social security system); "advocacia administrativa" (influence peddling); "associação com organização criminosa" (Criminal association); "concurso de crimes de tortura, corrupção passiva, extorsão, peculato, formação de quadrilha e receptação" (crimes of torture, passive corruption, extorsion, embezzlement, criminal association, and receipt of stolen goods); "corrupção passiva e facilitação ao descaminho/contrabando" (passive corruption and facilitation of smuggling or improper clearance); "roubo de armas" (robbery of firearms); "organização 
criminosa no interior dos presídios" (criminal association inside prison facilities); "dinheiro falso" (counterfeit money). The other two instruments, denounce and leniency agreement, appeared in few references of our corpus of analysis, probably because the corpus covered judgments that occur prior to the dissemination of the use of this practice in cases of grand corruption.

\section{FINAL CONSIDERATIONS}

Although grand corruption is more often disseminated in the media and the imaginary of the population, it is petty corruption that takes more time in the day to day of Brazilian Federal Justice in the courts in the South of the country. Through the analysis of the judgments it was found that the crimes of smuggling and improper clearance, especially in international border areas, constitute the majority of the corruption cases dealt with in the courts of TRF4, in addition to other criminal types involving low-level civil servants and small sums of money, when analyzed case by case. In a general perspective, it is possible to affirm that there is a reproduction of defendants and criminal organizations that are not corporations, and the categories of crimes observed are restricted to a dozen. As for grand corruption, it is identified on a small scale, involving middle- and high-echelon bureaucrats, more substantial sums of money, and more sophisticated crimes. These cases are targeted by large operations of the Federal Police and its technological instruments (such as telephone interceptions and wiretapping), and new legal tools (such as the denounces, plea bargain, and leniency agreements) that have guaranteed the recent visibility and institutional legitimacy of the triangle Federal Police, Public Prosecutor's Office at the federal level, and the Federal Justice.

It is difficult to know whether the answer to such difference between the number of petty and grand corruption cases lies in the empirical reality of the criminal activity in Brazil, or the justice system's criminal selectivity and its traditional choices for the crimes of the lowest strata of the population.

Therefore, this study suggests two complementary types of analysis: one is aimed at understanding the context of the crimes described in the research, by constructing typologies that involve examining the participation of public agents in corruption crimes, and expanding the analysis on the defendants' profile and the profile of their lawyers, exploring the work of the law firms and of the Public Defender's Office.

The second complementary analysis refers to the institutional changes and their effects, particularly regarding the creation of specialized criminal courts in the Federal Justice, and the dissemination of these courts throughout the country. This measure generated a separation between the judgment of petty corruption performed by regular courts and grand corruption (since it involves organized crime, money laundering, and corruption) by specialized courts.

To understand the difference in performance between specialized and regular courts, regarding the types of crimes, defendants' profile, and especially the procedures of criminal justice, measuring trial times, for instance, is an important objective of a research agenda that is currently underway.

We believe that this research and future studies under development can contribute to the knowledge about the role of the Federal Justice in the fight against corruption, so it transcends the current reactive role, as the last link of the chain in the network of accountability institutions.

Therefore, studying the Federal Justice's role is a crucial agenda for social sciences and Brazilian public policies. 


\section{REFERENCES}

Aranha, A. L. M. (2017). Accountability, corruption and local government: mapping the control steps. Brazilian Political Science Review, 11(2).

Arantes, R. B. (2011a). Polícia Federal e construção institucional. In L. Avritzer, \& F. Filgueiras (Orgs.), Corrupção e sistema político no Brasil (pp. 99-132). Rio de Janeiro, RJ: Civilização Brasileira.

Arantes, R. B. (2011b). The Federal Police and the Ministério Público. In T. Power, \& M. Taylor (Eds.), Corruption and democracy in Brazil: the struggle for accountability (pp. 184-217). Notre Dame, IN: University of Notre Dame.

Arantes, R. B., Loureiro, M. R., Couto, C., \& Teixeira, M. A. C. (2010). Controles democráticos sobre a administração pública no Brasil: Legislativo, tribunais de contas, Judiciário e Ministério Público. In M. R. Loureiro, F. L. Abrucio, \& R. S. Pacheco (Orgs.), Burocracia e política no Brasil: desafios para a ordem democrática no século XXI (pp. 109-147). Rio de Janeiro, RJ: Ed. FGV.

Avritzer, L. (2008). Introdução. In L. Avritzer, N. Bignotto, J. Guimarães, \& H. Starling (Orgs.), Corrupção: ensaios e críticas (pp. 11-18). Belo Horizonte, MG: Ed. UFMG.

Avritzer, L., \& Filgueiras, F. (2011a). Corrupção e controles democráticos no Brasil (Textos para Discussão Cepal-Ipea n. 32). Brasília, DF: Comissão Econômica para a América Latina e o Caribe \& Instituto de Pesquisa Econômica Aplicada.

Avritzer, L., \& Filgueiras, F. (Orgs.). (2011b). Corrupção e sistema político no Brasil. Rio de Janeiro, RJ: Civilização Brasileira.

Cardin, E. G. (2012). Trabalho e práticas de contrabando na fronteira do Brasil com o Paraguai. Geopolitica(s), 3(2), 207-234.

Carson, L., \& Prado, M. (2014, July). Mapping Corruption \& its Institutional Determinants in Brazil (IRIBA Working Paper No. 8). Manchester, England: International Research Initiative on Brazil and Africa.

Coacci, T. (2013). A pesquisa com acórdãos nas ciências sociais: algumas reflexões metodológicas. Mediações, 18(2), 86-109.

Costa, A. T. M., \& Oliveira, A., Júnior. (2016). Novos padrões de investigação policial no Brasil. Sociedade e Estado, 31(1), 147-164.
Filgueiras, F. (2008). Marcos teóricos da corrupção. In L. Avritzer, N. Bignotto, J. Guimarães, \& H. Starling (Orgs.), Corrupção: ensaios e críticas (pp. 299-306). Belo Horizonte, MG: Ed. UFMG.

Gloppen, S., Gargarella, R., \& Skaar, E. (2004). Democratization and the judiciary: the accountability function of courts in new democracies. London, England: Routledge.

Grimmer, J., \& Stewart, B. M. (2013, January). Text as data: the promise and pitfalls of automatic content analysis methods for political texts. Retrieved from https://web.stanford.edu/ jgrimmer/tad2.pdf

Justiça Federal da $4^{\text {a }}$ Região. (n.d.). Pesquisa de jurisprudência. Retrieved from http://jurisprudencia. trf4.jus.br/pesquisa/pesquisa.php?tipo $=1$

Krippendorff, K. (1989). Content analysis. In E. Barnouw, G. Gerbner, W. Schramm, T. L. Worth, \& L. Gross (Eds.), International encyclopedia of communication (Vol. 1, pp. 403-407). New York, NY: Oxford University Press.

Levcovitz, S. (2014, outubro). A corrupção e a atuação do Judiciário Federal 1991-2010. In Anais do 380 Encontro Anual da Anpocs. Caxambu, MG.

Lima, R. S., Ratton, J. L., \& Azevedo, R. G. (Orgs.). (2014). Crime, polícia e Justiça no Brasil. São Paulo, SP: Contexto.

Lipsky, M. (2010). Street-level bureaucracy, 30th Ann. Ed.: dilemmas of the individual in public service. New York, NY: Russell Sage Foundation.

Loureiro, M. R., Abrucio, F. L., \& Pacheco, R. S. (Orgs.). (2010). Burocracia e política no Brasil: desafios para a ordem democrática no século XXI. Rio de Janeiro, RJ: Ed. FGV.

Macaulay, F. (2011). Federalism and state criminal Justice systems. In T. Power, \& M. Taylor (Eds.), Corruption and democracy in Brazil: the struggle for accountability (pp. 218-249). Notre Dame, IN: University of Notre Dame.

Madeira, L. M., \& Geliski, L. (2017). Políticas sociais nos tribunais intermediários: tribunais regionais federais em evidência. Anuário de Derecho Constitucional Latinoamericano, 23, 305-326.

Mingardi, G. (2014). Crime organizado. In R. S. Lima, J. L. Ratton, \& R. G. Azevedo (Orgs.), Crime, polícia e Justiça no Brasil (pp. 318-324). São Paulo, SP: Contexto. 
Misse, M. (2014). Mercadorias políticas. In R. S. Lima, J. L. Ratton, \& R. G. Azevedo (Orgs.), Crime, polícia e Justiça no Brasil (pp. 198-203). São Paulo, SP: Contexto.

Oliveira, F. L., \& Silva, V. F. (2005). Processos judiciais como fonte de dados: poder e interpretação. Sociologias, 7(13), 244-259.

Pasquino, G. (2010). Corrupção. In N. Bobbio, N. Matteucci, \& G. Pasquino (Orgs.), Dicionário de política (pp. 293-291). Brasília, DF: Ed. UnB.

Power, T., \& Taylor, M. (2011a). Introduction: accountability institutions and political corruption in Brazil. In T. Power, \& M. Taylor (Eds.), Corruption and democracy in Brazil: the struggle for accountability (pp. 1-28). Notre Dame, IN: University of Notre Dame.

Power, T., \& Taylor, M. (Eds.). (2011b). Corruption and democracy in Brazil: the struggle for accountability, IN: University of Notre Dame.

Praça, S., \& Taylor, M. M. (2014). Inching toward accountability: the evolution of Brazil's anticorruption institutions, 1985-2010. Latin American Politics and Society, 56(2), 27-48.

Provalis Research. (2010). WordStat 6: content analysis module for QDA Miner \& SimStat. User's guide. Montreal, Canada: Author.
Sinhoretto, J. (2014). Seletividade penal e acesso à Justiça. In R. S. Lima, J. L. Ratton, \& R. G. Azevedo (Orgs.), Crime, polícia e Justiça no Brasil (pp. 400410). São Paulo, SP: Contexto.

Transparency International. (n./d.a). What is corruption? Transparency International online page, without pagination, publication date. Retrieved from https://www.transparency.org/ what-is-corruption\#define

Transparency International. (n./d.b). Anticorruption glossary: political corruption. Transparency International online page, without pagination, publication date. Retrieved from https://www.transparency.org/glossary/term/ political_corruption

Verd, J. M., \& Lozares, C. (2014). Reconstructing social networks through text analysis: from text networks to narrative actor networks. In, S. Domínguez, \& B. Hollstein (Eds.), Mixed methods social networks research: design and applications (pp. 269-304). Cambridge, MA: Cambridge University Press.

Warren, M. E. (2004). What does corruption mean in a democracy? American Journal Of Political Science, 48(2), 328-343.

\section{Lígia Mori Madeira}

https://orcid.org/0000-0003-3657-3153

$\mathrm{PhD}$ in sociology; Professor at the Graduation Program in Public Policies and Political Sciences of the Federal University of Rio Grande do Sul (UFRGS); Researcher of the research group Violence and Citizenship (GPVC/ UFRGS); Coordinator of the Research Group on Development, Rights, Institutions and Public Policies (NEDIPP/ UFRGS). E-mail: ligiamorimadeira@gmail.com

\section{Leonardo Geliski}

https://orcid.org/0000-0001-6948-761X

PhD student and master's in public policies from the Federal University of Rio Grande do Sul (UFRGS); Degree in law from the Ritter dos Reis University Center (UNIRITTER) and a degree in public policies from UFRGS; Researcher at the Research Group on Rights, Institutions and Public Policies (NEDIPP/UFRGS).

E-mail: leonardo.geliski@ufrgs.br 


\section{APPENDIX}

\section{Dictionary of types of crimes, used for the analysis and frequency of words.}

Box A below presents the words (in Brazilian Portuguese) found in the dictionary analysis and classified as key-terms to process the text analysis in the software WordStat. With the term, the box shows the type of crime, according to Brazilian legislation.

\section{BOX A WORDS OF THE DICTIONARY ANALYSIS AND THE RELATED TYPE OF CRIME}

\begin{tabular}{|c|c|c|c|}
\hline Term (analyzed in Brazilian Portuguese) & Crime & Norm $(*)$ & Item \\
\hline Abuso de Autoridade & Abuse of Authority & Law on Abuse of Authority & Art. 3 \\
\hline Advocacia Administrativa & Influence peddling & Brazilian Criminal Code & Art. 321 \\
\hline Apropriação Indébita & Embezzlement & Brazilian Criminal Code & Art. 168 \\
\hline Associação para o Tráfico & Association with drug trafficking & Law on Drugs & Art. 35 \\
\hline Calúnia & Slander & Brazilian Criminal Code & Art. 138 \\
\hline Concussão & Graft & Brazilian Criminal Code & Art. 316 \\
\hline $\begin{array}{l}\text { Conduzir veículo automotor sob a } \\
\text { influência de álcool }\end{array}$ & $\begin{array}{l}\text { Driving under the influence of } \\
\text { alcohol }\end{array}$ & Brazilian Traffic Code & Art. 306 \\
\hline Contrabando & Smuggling & Brazilian Criminal Code & Art. 334-A \\
\hline Contrabando de Agrotóxico & Smuggling & Brazilian Criminal Code & Art. 334-A \\
\hline Corrupção Ativa & Active corruption & Brazilian Criminal Code & Art. 333 \\
\hline Corrupção de Menor & Petty corruption & Brazilian Criminal Code & Art. 218 \\
\hline Corrupção de Testemunha & Witness intimidation & Brazilian Criminal Code & Art. 343 \\
\hline Corrupção Passiva & Passive corruption & Brazilian Criminal Code & Art. 317 \\
\hline Crime Ambiental & Environmental crimes & Law on Environmental Crimes & Complete norm \\
\hline Crime contra a Ordem Tributária & Crimes Against the Tax System & $\begin{array}{l}\text { Law on Crimes Against the Tax } \\
\text { System }\end{array}$ & Complete norm \\
\hline Dano & Damage & Brazilian Criminal Code & Art. 163 \\
\hline Descaminho & Improper clearance & Brazilian Criminal Code & Art. 334 \\
\hline Difamação & Defamation & Brazilian Criminal Code & Art. 139 \\
\hline Emprego de Fraude & Aggravated theft & Brazilian Criminal Code & Art. 155, § 4, III \\
\hline Estelionato & Larceny & Brazilian Criminal Code & Art. 171 \\
\hline Estelionato contra a Previdência & Larceny & Brazilian Criminal Code & Art. 171, § 3 \\
\hline Estelionato Previdenciário & Larceny & Brazilian Criminal Code & Art. 171, § 3 \\
\hline
\end{tabular}


RAP | The Federal Justice act in combating corruption in Southern Brazil

\begin{tabular}{|c|c|c|c|}
\hline Term (analyzed in Brazilian Portuguese) & Crime & Norm $\left(^{\star}\right)$ & Item \\
\hline $\begin{array}{l}\text { Estelionato Saque Fraudulento de } \\
\text { FGTS }\end{array}$ & Larceny & Brazilian Criminal Code & Art. $171, \S 3$ \\
\hline Evasão de Divisas & Tax evasion & Law on White-collar Crimes & Art. 22 \\
\hline $\begin{array}{l}\text { Facilitação de Contrabando ou } \\
\text { Descaminho }\end{array}$ & $\begin{array}{l}\text { Smuggling facilitation or } \\
\text { improper clearance }\end{array}$ & Brazilian Criminal Code & Art. 318 \\
\hline Falsificação de Documento Público & Falsification of public documents & Brazilian Criminal Code & Art. 293 \\
\hline Falso Testemunho & $\begin{array}{l}\text { False testimony or False expert } \\
\text { opinion }\end{array}$ & Brazilian Criminal Code & Art. 342 \\
\hline Fraude & Larceny & Brazilian Criminal Code & Art. 171 \\
\hline Fraude contra o INSS & Larceny & Brazilian Criminal Code & Art. 171, § 3 \\
\hline Furto & Theft & Brazilian Criminal Code & Art. 155 \\
\hline Furto Qualificado & Aggravated theft & Brazilian Criminal Code & Art. $155, \S 4$ \\
\hline Homicídio & Homicide & Brazilian Criminal Code & Art. 121 \\
\hline $\begin{array}{l}\text { Importação de Medicamento sem } \\
\text { Autorização }\end{array}$ & $\begin{array}{l}\text { Import medical product without } \\
\text { registration with sanitation } \\
\text { agency }\end{array}$ & Brazilian Criminal Code & $\begin{array}{l}\text { Art. 273, §1-B, } \\
\text { I e Art. 334-A, } \\
\quad \S 1, \|\end{array}$ \\
\hline Injúria & Slander & Brazilian Criminal Code & Art. 140 \\
\hline Lavagem de Dinheiro & $\begin{array}{l}\text { Laundry or concealing of assets, } \\
\text { right, and values }\end{array}$ & Law on Money Laundering & Art. 1 \\
\hline Lesão Corporal & Personal injury & Brazilian Criminal Code & Art. 129 \\
\hline Manter em Depósito de Agrotóxico & Irregular storage of pesticides & Law on Environmental Crimes & Art. 56 \\
\hline $\begin{array}{l}\text { Obtenção de Financiamento mediante } \\
\text { Fraude }\end{array}$ & False loan application & Law on White-collar Crimes & Art. 19 \\
\hline Peculato & Embezzlement & Brazilian Criminal Code & Art. 312 \\
\hline Porte llegal de Arma & Illegal possession of firearms & Statute of Disarmament & Art. 16 \\
\hline Prevaricação & Prevarication & Brazilian Criminal Code & Art. 319 \\
\hline Quadrilha ou Bando & Criminal association & Brazilian Criminal Code & Art. 288 \\
\hline Receptação & Receipt of stolen property & Brazilian Criminal Code & Art. 188 \\
\hline Roubo & Robbery & Brazilian Criminal Code & Art. 157 \\
\hline Roubo Qualificado & Aggravated robbery & Brazilian Criminal Code & Art. 157, § 2 \\
\hline Sonegação Fiscal & Tax evasion & Law on Tax Evasion & Art. 1 \\
\hline Tentativa de Homicídio & Homicide & Brazilian Criminal Code & Art. 121 \\
\hline Tráfico de Influência & Influence peddling & Brazilian Criminal Code & Art. 332 \\
\hline Tráfico llícito de Entorpecentes & Drug trafficking & Law on Drugs & Art. 33 \\
\hline Tráfico Internacional de Entorpecentes & International drug trafficking & Law on Drugs & $\begin{array}{l}\text { Art. } 33 \text { com Art. } \\
\qquad 40,1\end{array}$ \\
\hline
\end{tabular}




\begin{tabular}{|c|c|c|c|}
\hline Term (analyzed in Brazilian Portuguese) & Crime & Norm $\left(^{\star}\right)$ & Item \\
\hline Tráfico Interno de Entorpecentes & Drug trafficking & Law on Drugs & Art. 33 \\
\hline Transporte de Agrotóxicos & $\begin{array}{l}\text { Irregular transportation of } \\
\text { pesticides }\end{array}$ & Law on Environmental Crimes & Art. 56 \\
\hline Uso de Documento Falso & Use of false document & Brazilian Criminal Code & Art. 304 \\
\hline
\end{tabular}

Source: Elaborated by the authors.

\section{Key (*):}

Brazilian Criminal Code

Brazilian Traffic Code

Statute of Disarmament

Law on Abuse of Authority

Law on Crimes Against the Tax System :

Law on Drugs

Law on Money Laundering

Law on White-collar Crimes

Law on Environmental Crimes

Law on Tax Evasion
: $\quad$ Decree-Law 2848/1940

: Federal Law 9503/1997

Federal Law 10826/2003

: Federal Law 4898/1995

: Federal Law 8137/1990

: Federal Law 11343/2006

: Federal Law 9613/1998

: Federal Law 7492/1986

: Federal Law 9605/1998

: Federal Law 4728/1965

\section{TABLE A NUMBER OF WORDS/DIFFERENT TERMS PER NORM}

\begin{tabular}{lc}
\multicolumn{1}{c}{ Norm } & Terms \\
\hline $\begin{array}{l}\text { Brazilian Criminal Code } \\
\text { Law on Drugs }\end{array}$ & 04 \\
\hline Law on Environmental Crimes & 03 \\
\hline Law on White-collar Crimes & 02 \\
\hline Statute of Disarmament & 01 \\
\hline Law on Abuse of Authority & 01 \\
\hline Law on Crimes Against the Tax System & 01 \\
\hline Law on Money Laundering & 01 \\
\hline Law on Tax Evasion & 01 \\
Brazilian Traffic Code & 01 \\
\hline
\end{tabular}

Source: Elaborated by the authors. 
RAP | The Federal Justice act in combating corruption in Southern Brazil

\section{TABLE B FREQUENCY OF WORDS PER OCCURRENCE IN THE CASES (FORM 8)}

\begin{tabular}{|c|c|c|c|}
\hline Term (analyzed in Brazilian Portuguese) & Term in English & Frequency & Number of cases \\
\hline Contrabando & Smuggling & 4392 & 27 \\
\hline Descaminho & Improper clearance & 1924 & 26 \\
\hline Corrupção Ativa & Active corruption & 1592 & 27 \\
\hline Lavagem de Dinheiro & Money laundering & 875 & 26 \\
\hline Dano & Damage & 716 & 27 \\
\hline Fraude & Fraud & 691 & 26 \\
\hline Estelionato & Larceny & 651 & 27 \\
\hline Corrupção de Menor & Corruption of minors & 533 & 26 \\
\hline Associação para o Tráfico & Association with drug trafficking & 237 & 23 \\
\hline Furto & Theft & 223 & 21 \\
\hline Receptação & Receipt of stolen property & 207 & 22 \\
\hline Concussão & Graft & 187 & 22 \\
\hline Uso de Documento Falso & Use of false document & 166 & 22 \\
\hline Porte llegal de Arma & Illegal possession of firearms & 130 & 21 \\
\hline Quadrilha ou Bando & Criminal association & 125 & 20 \\
\hline Tráfico Internacional de Entorpecentes & International drug trafficking & 121 & 23 \\
\hline Falso Testemunho & False testimony & 102 & 15 \\
\hline Tráfico llícito de Entorpecentes & Drug trafficking & 99 & 19 \\
\hline Sonegação Fiscal & Tax evasion & 99 & 16 \\
\hline Prevaricação & Prevarication & 85 & 16 \\
\hline Facilitação de Contrabando ou Descaminho & $\begin{array}{l}\text { Smuggling facilitation or improper } \\
\text { clearance }\end{array}$ & 66 & 17 \\
\hline Importação de Medicamento sem Autorização & $\begin{array}{l}\text { Non-authorized importation of medical } \\
\text { product }\end{array}$ & 66 & 15 \\
\hline Tentativa de Homicídio & Attempted murder & 46 & 8 \\
\hline Roubo Qualificado & Aggravated robbery & 37 & 9 \\
\hline Lesão Corporal & Injury & 22 & 14 \\
\hline Estelionato contra a Previdência & Larceny against the social security system & 20 & 10 \\
\hline Extorsão Mediante Sequestro & Kidnapping with ransom & 15 & 8 \\
\hline Abuso de Autoridade & Abuse of authority & 14 & 5 \\
\hline Obtenção de Financiamento mediante Fraude & False loan application & 8 & 6 \\
\hline
\end{tabular}

Source: Elaborated based on the research data using the software WordStat. 